\title{
Social Media and the 212 Islamic Movement
}

\author{
M M Muharam ${ }^{1}$, K Marijan² \\ Lecturer in Political Science at UniversitasDarulUlum.Jl Gus Dur No 29A, Jombang $61419^{1}$ \\ Professor in Political Science, UniversitasAirlangga UNAIR, JlAirlagga 4-6 Surabaya 60286. Telephone: \\ (031) $5034015^{2}$ \\ \{m3_mubarok75@yahoo.co.id ${ }^{1}$, kacung.marijan@fisip.unair.ac.id $\left.{ }^{2}\right\}$
}

\begin{abstract}
The 212 movement is not only a movement but also a label for the action of certain Islamic groups. The ability to organize the movements and carry out pressure cannot be separated from the use of political identity issues and social media. The digital age has enabled these groups to articulate their interests and support mobilization through social media. Some social media platforms that are used by the Islamic group to strengthen their movement include YouTube, Facebook, Twitter, Instagram, Line, and WhatsApp. Officially, this group created an account of defending Islamic action on various social media platforms. In the Islamic defender action account, this group constructs the importance of action to carry out political and religious struggles. In addition, to neutralize the opinions of the scholars, the 212Islamic group also gave the rise to the opinion of political elites in the government to legitimize the movement itself. The example is the opinions of the political elites in the government that were raised in the demonstration on 2 nd of December 2016. Through social media, these opinions were constructed and interpreted to influence public opinion. To strengthen the legitimacy of the movement, this group produced several statements from some moderate Islamic groups. Those groups were identified as opposite groups of the 212 Islamic Group. Opinions from some moderate Islamic figures who were believed to be advantageous to their groups would be distributed via social media. Moreover, to create an official account on social media, there are main figures from the 212 Islamic movement who also create personal accounts on it. These figures regularly carry out the activities on social media via live stream to strengthen the movement.
\end{abstract}

Keywords: Political identity, 212 Islamic groups, Social media

\section{Introduction}

The information age has placed communication and information technology as the most important part in shaping social and political influence. According to Castells [1], current political contestation and identity clashes cannot be separated from the involvement of information and technology. In order to gain influence and political power, political actors have used the new 
technological instruments. The current century is also known as the internet age, where the internet has a role in creating political meaning, political stories, and political control [2]. Through internet, political idea and message are easily conveyed in a relatively fast time and can expand and then create a historical momentum. Arab Spring is an example of the influence of internet technology is changing the political system. Information technology has been used as a mobilization instrument of popular movements to undermine authoritarian governments [3].

The Arab Spring was preceded by a demonstration movement from various groups, especially groups of educated young people who experienced unemployment and demanded that Ben Ali resigns as president of Tunisia. The large-scale demonstration was triggered by a young man Mohamed Bouazizi who was unwilling to pay a bribe to the government and chose to set himself on fire as a protest. Through YouTube and Al Jazeera, the action of Bouazizi was broadcasted continuously and widely. This broadcast aroused sympathy and was followed by resistance through the popular movement, which led to the downfall of Ben Ali's administration. Inspired by Tunisia, a student from Egypt, waged a revolution through her Facebook page to end famine and poverty that struck Egypt. The action then spread and led to a revolution in Egypt, demanding the end of Hosni Mubarak administration.

In dealing with authoritarian governments, the mass media are often used as tools of struggle by civil society to fight against the authorities and strengthen human rights enforcement [4]. To reduce the influence of the mass media, authoritarian authorities usually control the content of the news and revoking the licenses for newspapers and printing-press. On the other hand, in such authoritarian countries, there are mass media that have idealism to criticize and support criticism from civil society to the authorities.

Unlike conventional mass media, new media such as social media are relatively more independent from the intervention of the authorities. Therefore, it becomes easier to use social media as an alternative instrument to criticize the deviations of the authorities. Social media are alternatives to voice ideas or good values in the social and political world. As an alternative media based on the latest technology, namely the internet, social media have a role to articulate interests, organize resources and people and to achieve goals [5].

This study is intended to discuss the use of social media in the 212 Islamic movements, an attribute is given to a series of movements carried out by Islamic groups in expressing their voices against the authorities. The phenomenon of the 212 movements becomes interesting not only because it has involved millions of peoples, but also it has become a force of pressure on authorities.

\section{Method}

The data used in this study were based on in-depth interviews with four main figures in the 212 Islamic group and one figure from the Moderate Islamic Group (NU). In addition, observations were made on the content of social media created by the 212 Islamic groups. A series of actions carried out by the 212 groups was also observed. Online observations of social media aimed to find out the formation of identity and social construction and the existence of related groups [6]. 
Observation of social media can also be used to determine the formation of social relations through cyberspace [7]. By observing social media, resistance to government policies can be identified [8]. Through content analysis of social media, the meaning of the content that appears in social media can be understood [9].

\section{Result and Discussion}

\subsection{The 212 Group}

The term ' 212 ' refers to a large-scale demonstration that was attended by millions of Muslims on December 2, 2016. The main issue of the demonstration was a demand for the trial of then Jakarta Governor 'Ahok'Basuki Tjahaja Purnamabecause he was considered to have blasphemed the teachings of Islam, especially Al-Maidah verse 51, and the ulema. Previously, similar demonstrations had been held on October 14 and November 4, 2016, with the same demands. However, because those two 'Actions to Defend Islam' did not get a meaningful response, the third demonstration and 'Action to Defend Islam' were held, involving millions of protesters who came from various regions in Indonesia. The demand of the protesters was a response to earlier statements of Ahok on September 27, 2016, in the KepulauanSeribu Regency. A snippet of the speech video was posted by BuniYani on his Facebook account, which then sparked a reaction from netizens.

The Indonesian Ulema Council (MUI) had conducted a special review of Ahok's remarks on October 11 and issued a statement of attitude saying,'It is haram to state that surah Al-Maidah verse 51, which forbids Muslims to elect Jews and Christians as leaders, is a lie and itis included as desecration of Al-Quran'. The statement of the attitude was then used as a starting point to tryAhokfor blasphemy. This can be seen from the formation of the National Movement to Guard the MUI Fatwa (GNPF MUI), which became one of the main motors of a series of anti-Ahok demonstrations, in addition to the Islamic Defenders Front (FPI).

The 212 demonstrations have created a new phenomenon which, according to Bayat (1979), was called 'street politics'. Even when Ahok was already tried and convicted, a series of actions continued. The movement has also been used as momentum by Islamic groups to oppose JokoWidodoadministration and organize themselves as an opposition group called the 'Presidium Alumni 212'. This group, on several occasions, has made the 'street' space for their belief and movement to represent disappointment, while forging identity, strengthening solidarity, and expanding the discourse of protest at the same time (Bayat, 2010).

As stated by secretary-general of the Islamic Community Forum (FUI), Al Khaththath [10], the statement of Ahokthat was allegedly defamed religion was the main reason for that movement. The statement has fostered growing religious sentiment, especially among urban Muslims. The spirit of returning to the path of religion and Hijrah, an Arabic for 'migrate', is quite prominent among educated Muslims and the urban middle class. The phenomenon of hijrah is part of the resurgence of Islamic conservatism in recent decades [11]. This spirit has created the strengthening of Islamic identity through certain symbols, such as clothing and facial appearance. Muslims who have this new spirit is relatively easy to build solidarity together, in the form of defense, when Islam gets 'attacked'. 
The strengthening of Islam in Indonesia is contrary to the modernization theory that proposes 'the death of religion' (Inglehart and Norris, 2004: 1). Such a theory is indeed debated when it is associated with what is happening in society, including in society in the United States. Berger said 'secularization theory is essentially mistaken' (Berger, 1999: 2). Therefore, in contrast to the modernization theory that considers religion to be increasingly marginalized, Berg-Sorensen said that religion can play a legitimate role in public debates and political life (2006: 800). However, as stated by van Bruinessen, what happened in Indonesia is not merely the strengthening of religion, in this case, Islam, but the strengthening of conservative views that in various cases, creates intolerant attitudes, views, and behavior.

The rise of identity politics is interconnected with the existence of a religion-based populism movement [12]. If the populism movement usually arises merely as a reaction to the establishment and injustice, religion-based populism movement is a movement to challenge the establishment and economic inequality based on certain religious groups. Populism movement itself can grow in countries of which people experience a high level of social inequality, which is in Indonesia is in 'yellow grade', around 0.4according to ginirasio. Compared to the wealth of ordinary Indonesians, the wealth of small groups of wealthy Indonesians has been increasing very fast in the last two decades. In 2017, Oxfam reported that the wealth of 4 richest people in Indonesia was equivalent to the wealth of 100 million poor people (the Guardian, 2017). This socioeconomic gap widens when it is associated with ethnicity and religion. The majority of the groups that are categorized as rich groups are of ethnic Chinese who adhere to non-Muslim religions.

The 212 movements, in such a context, cannot be understood solely as a movement to strengthen religious conservatism. The movement is also related to economic interests. Those who were involved in the action were large groups, namely urban educated groups, who were critical but were not yet economically stable, and urban poor groups. Hadiz [12] who cited previous studies, said that many urban poor in Jakarta had joined the ForumBetawiRembuk (FBR) and FPI as a strategy for their economic stabilities.

\subsection{Media Influence}

In addition to such contexts, media such as television and newspapers, and internet-based media have a major contribution to the formation and enlargement of the 212 movements. The upload of video snippets of Ahok by BuniYani, which later went viral, has become a spark for the emergence of shared awareness of doing resistance to Ahok. What was released through social media was more prominent when conventional media echoed it so that the dissemination of information about the 212 movements was even more massive.

Further, mobilization and organization of the 212 movements had also been carried out through social media. Invitation, mobilization, and organization of movements through social media are faster and cheaper. Smartphone users who have WhatsApp, for example, could do those tasks so easily, cheaply, and quickly, so that the chain of information related to 212 quickly spread. Shobri Lubis [13]. Chair of the FPI also acknowledged the power of social media in organizing the 212 movements. In each action, they never forgot to make hashtags (\#) with certain topics go viral, such as \#imprisonAhok, \#peaceaction, and \#defendingislam.

Awareness of the benefits of social media to strengthen the action had been more prominent ahead of the demonstration on December 2, 2016. Activists who are members of the GNPF MUI, 
sympathizers and supporters of the action actively use YouTube, Facebook, Twitter, Instagram, Line, and WhatsApp. This group officially created an account for action to Defend Islam III on various social media. Creating hashtag (\#) Action to Defend Islam III aimed to create sentiments or willingness among Muslims to succeed in the 212 Islamic movements. This group also published the opinions of religious leaders who are from groups that actually are not in the same line of thinking, inter alia, the opinion of Kyai Miftachul Akhyar, deputy Rais'Aam PBNU, who said that Ahokshould is detained before the December 2 demonstration.

Besides using social media as instruments to spread information on action plans, this group also framed the information on social media so that the impact of their actions became wider. For example, when there was an appeal from the government, especially the police, for not taking part in the action, there was a live broadcast from a YouTube channel about the action of people from Ciamis who carried out a long march to Jakarta. This action bred sympathy and reinforced others to carry out similar actions. According to Shobri Lubis [13], the action of people from Ciamis on that YouTube channel gave an impression of the courage of the movement leaders and participants to be totally involved in a protest called the Action to Defend Islam. For him, it is a message and a sign that the 212 actions could not be stopped and was a symbol of the revival of Muslims.

The GNPF MUI that was one of the main initiators of the 212 movements realized that it was impossible for them to have an open confrontation with all national elites. They were more likely to make a movement by attracting the greatest possible sympathy from the public through various media. Besides popularizing the hashtag (\#) Action to Defend Islam, they also spread the opinion of Vice President JusufKalla stating, "Allow the mass demonstration on December 2 to be held".

Awareness of the importance of social media in spreading ideas has long been held by the Chairman of the GNPF MUI, Bachtiar Nasir, even long before the 212 actions. Unlike most preachers who rely more on the conventional sermon, Nasir has long been aware of the importance of doing dawah through new technology media such as social media. Through the Ar-Rahman Qur'anic Learning (AQL) Islamic Center, the religious institution he founded, Nasir actively produces and spreads the spirit of struggle through live streams on YouTube once a week. Nasir believes that he has succeeded in producing ideological cadres as the successors of his struggle through social media. In a sermon on YouTube stream, Nasir advised the younger generation to be politically affiliated with organizations that fight for the interests of Islam.

Targeting young people through social media is inevitable. Apart from being the most active users, young people have become the most productive producers and disseminators of news on social media. Their ability to easily adapt to the advancement of information technology makes it easy for them to utilize internet-based technology to influence public opinion. Additionally, the nature of social media that are easily accessed gives a greater degree of autonomy, or does not receive significant obstacles from a public authority, and becomes an unrestricted public space [14]. Through its autonomous nature and characteristics, social media are difficult to be intervened by the authorities.

\subsection{The 212 Movement and Mainstream Islamic Groups}

It must be admitted that compared to mass organizations and political parties, the 212 Islamic group is more connected with technological advancements. The 212 Islamic group, which is 
incorporated in the GNPF MUI, basically consists of various Islamic groups. The statement of Ahok as their common concern and interest has united them. MUI Chairperson who is also Rais 'Aam of PB NU, KH Ma'ruf Amin, also became part of the group. Therefore in the early days of the 212 movements, the participants of the movement were actually not only groups and sympathizers from nonmainstream Islamic organizations, such as the AQL, the Islamic Community Forum (FUI), FPI, Jama'ahTarbiyah (JT), and Hizbut-Tahrir Indonesia (HTI). Some members of NU and Muhammadiyah, which have been categorized as mainstream and moderate Islamic groups, also joined the 212 movements. However, in its development, those who actively managed the movement were nonmainstream Islamic organizations.

These nonmainstream Islamic organizations initially grew strongly on prominent campuses in Indonesia (Van Dijk and Kaptein, 2010); [15]. The repressiveness of the New Order regime has pushed some campus activists to carry out cultural resistance through Islamic learning movements on campuses. In addition, the emergence of these organizations was also influenced by the success of the Islamic Revolution in Iran and the Ichwanul Muslimin movement in Egypt. After graduation, activists continued their movements outside the campus, albeit in different settings.

The character of group membership consisting of well-educated young people makes them familiar and active in using new media. During this time, they have also been actively using social media to form Islamic discourse [16]. This pattern was later adopted by the 212 Islamic group that used social media to shape religious and political influence. At the beginning of the reform to date, religious discourse on social media is relatively more dominated by Islamic groups who want the establishment of an Islamic state or a state based on Islamic law.

Through their activities, the 212 Islamic group movement expressed anxiety towards Joko Widodo administration that is seen as a secular administration of which policies often harm Muslims. This group perceives that a secular and liberal capitalist system of government will make Islam an economically and politically marginal group. Secularism and liberal capitalism are seen as capable of causing moral decadence in mankind. In this context, this group is in line with the perspectives of the first generation of critical theoreticians, such as Theodor Adorno, Herbert Marcuse, and Max Horkheimer, who claimed that secular capitalism has led to disorientation and dehumanization [17].

Hostility towards the secular capitalist system is one of the reasons for this group to take a stand in opposition to other Islamic groups that are considered to be very accommodating towards the practices and values of secular capitalism [12]. Mainstream religious organizations are not only accused of accepting views on the ideology of the secular state, but also accused of being close to oligarchic power. In this context, it becomes reasonable if the 212 Islamic group has the courage to take a different position from NU, because this group holds that $\mathrm{NU}$, as the mainstream Islamic organization, has strengthened the continuity of the secular capitalism.

Social media is an instrument for the 212 groups to gain sympathy and support from Muslims who do not have an emotional attachment and religious affiliation with moderate Islamic organizations. Muslims who have such typologies will be easily formed and mobilized to support such movements [18]. For Nasir, one form of ideological work is to shape the awareness of these neutral Muslims to become supporters of the 212 Islamic movement. In addition, by using social media it will be easy for this group to influence the 'floating' Muslims. Many Muslims are affiliated with NU and Muhammadiyah, but they do not feel obliged to obey the instructions of the two organizations in social, political or religious matters [12]. According to Hadiz, Muslims who 
were categorized as 'floating' Muslims were the most numerous participants in Action to Defend Islam III.

Awareness about the importance of social media in the development of religious discourse in society actually does not only emerge in young groups affiliated with the 212 Islamic groups. Mainstream Islamic groups, such as NU and Muhammadiyah, also use information technology. An activist from the moderate Islamic group NU, UlilAbsharAbdalla, is one of those who are actively doing dawah through social media. Abdalla is so active with his dawah through social media that he is often referred to as 'online kyai' by his colleagues. In the last three years, Abdalla has been conducting a special study of Ihya 'Ulumuddin, a book written by Imam al-Ghazali, and several other books through a live stream on his Facebook account. Besides Abdalla, many Islamic boarding schools broadcast religious teachings through social media as well. Doing dawah through online media is not merely as part of the adaptation to the development of communication and information technology, but also as a response to balance the online dawah conducted by the 212 Islamic groups so that Muslims will have another perspective.

However, mainstream Islamic organizations tend to be more defensive in public affairs [19]. This is because the 212 Islamic group is not only actively fighting against the authorities, but also actively developing religious social discourse on online media and social media. If then this organization begins to actively create counter-discourse on online media and social media, what follows is what Michael Foucault calls a discourse war, which will probably occur in the social and political world [20]. Such a war is very clear when religious discourse comes into contact with political discourse, as happened in the presidential election in 2019.

\section{Conclusion}

The 212 Islamic group consists of people and groups who had been developing alternative Islamic movements. These groups do not only actively develop a discourse about the importance of the application of Islamic teachings in daily life, but also actively carry out resistance movements against authorities and societies that are considered to be secular. New information and communication technology and developing democracy today are used as instruments to develop a discourse about the importance of applying Islamic teachings entirely and also to exert pressure on the authorities. Although their values are essentially contradictory to the values of modern democracy, they use the current democratic climate in Indonesia as an instrument. They claim that conducting religious teachings, holding demonstrations, and making demands are part of freedom of expression in a democracy.

The strengthening of Islamic conservatism within the 212 Islamic groups has led to counterdiscourse through the internet and social media by mainstream Islamic groups, such as NU and Muhammadiyah, which tend to take the moderate path. This counter-discourse, on the one hand, reflects the battle of ideas about Islam and its implementation in the life of society, nation, and state in Indonesia, but on the other hand, it also allows the public to obtain diverse information about Islam. Such discourse war will affect the politics of Islam in Indonesia whether it tends to be moderate, continues to clash, or will be dominated by conservative and radical interpretations [21]. The long history of Islam in Indonesia so far has shown that discourse war is not always in the form of war that negates each other, but also dialogue and mutual learning from one another. 


\section{References}

[1] M. Castells, The Power Of Identity. United Kingdom: West Sussex: Wiley Blacwel, 2010.

[2] F. Ginsburg, D. Hesmondhalg, and J. Toyenbee, "Rethingking the Digital Age," in The Media and Social Theory, New York: Routledge, 2008, pp. 127-144.

[3] M. Castells, Networks Of Outrage and Hope. Cambridge: Polity Press, 2012.

[4] R. . Alexander, J. C and Jacob, Mass Communication, Ritual and Civil Society' in Liebes,Tamar dan Curran, James (ed).Media, Ritual and Identity. London: Routledge, 1998.

[5] L. A. Lievrouw, Alternative and Activist New Media. 2011.

[6] A. N. Markham, N. K. Denzin, and S. Lincoln, Yvonna, "Metode, Politik dan Etika Refresentasi dalam Etnografi Online," in Qualitative Research 2, Yogyakarta: Pustaka Pelajar, 2011, pp. 164-194.

[7] R. Bury, S. Littlejohn, and K. A. Foss, "Digital Culture," Communication Theory. Sage Publication, California, pp. 309-310, 2009.

[8] J. Hartley, Communication,Cultural and Media Studies,The Key Concepts. London: Routledge, 2002.

[9] P. Manning, B. Swan, N. K. Denzin, and Y. S. Lincoln, "Analisis Naratif, Konten dan analisis Semiotik," in Handbook of Qualitative Research, 2009, pp. 613-629.

[10] Khaththath, "Interview," 2019.

[11] M. van Bruinessen, "Contemporary Developments in Indonesian Islam:Explaining the Conservative Turn,” Singapore Inst. Southeast Asian Stud., 2013.

[12] V. R. Hadiz, "The floating Ummah in The fall of Ahok in Indonesia," Sogang Univ. Trans-Regional abd-National Stud. Southeast Asia J., pp. 1-20, 2018.

[13] S. Lubis, "Interview," 2019.

[14] T. V Ford and G. Gil, Radical Internet Use. Dalam J. D. Downing (editor), Radical Media, Rebellious Communication and Cocial Media. California: Sage Publications, 2001.

[15] M. Woodward, "Getting Culture: A New Path for Indonesia Islamist Justice and Prosperity," Cont Islam Journal. Springer Verlag, pp. 173-189, 2013.

[16] M. Tempo, "Muslim Konservatif, Saleh atau Salah, 19-25 Juni 2017.”.

[17] Sindhunata, Dilema Manusia Rasiona. Jakarta: Gramedia, 1983.

[18] B. Natsir, "Interview.” 2019. 
[19] R. Hefner, Islamization and The Changing Ethical Imagination in Java, vol. 96. Indonesia: Cornell University Southeast Asia Program, 2013.

[20] V. R. . Foucault, M., Power/Knowledge. New York: The Harvetes Press, 1977.

[21] P. Mandaville, Global Political Islam. Canada: Routledge, 2007. 